\title{
A NOVA TITULAR, PROFESSORA IVETTE SENISE FERREIRA, PROFERE SEU DISCURSO DE POSSE
}

Nesta oportunidade em que somos recebidos por esta Congregação para solenemente tomar posse nos cargos de Professor Titular da Faculdade de Direito da Universidade de São Paulo, faço coro às palavras daqueles que me precederam nesta festividade, confirmando o mesmo júbilo e a mesma emoção que sentimos no instante em que oficialmente se confirma termos chegado à etapa final do árduo caminho percorrido, na conquista do título agora definitivamente incorporado em nossas vidas.

Mais significativa se torna esta solenidade por contarmos com a homenagem de nossos pares, na saudação que nos é dirigida por um de seus representantes, no meu caso corporificada na eminente Professora Ada Pellegrini Grinover, o que me honra e desvanece, figura ímpar de mestra, amiga, colega e companheira, jurista insígne, advogada de escol, que por ter-me precedido na carreira pode propiciar-me este momento inolvidável em que a cordialidade de sua apresentação, o carinho de suas palavras e a generosidade de um imerecido louvor vieram estreitar os laços desenvolvidos em décadas de convívio, que alternadamente nos puseram lado a lado, frente a frente, ou em críticas situações de confronto.

Este momento me faz lembrar tantos outros em que aqui estivemos, como alunas da Faculdade e colegas de turma, ouvindo e admirando os professores da época, vibrando com seus desempenhos, presentes aos seus concursos, às suas posses, sem imaginar que aqui também estaríamos um dia, saudando e sendo saudadas, na companhia de outros colegas que também ousaram, como nós, ocupar o lugar dos mestres que se retiram.

Juntas iniciamos a nossa escalada, desenvolvendo as nossas aptidões e afinidades, nos estudos e nas leituras, e em algumas aventuras acadêmicas, quando defendíamos, nas quadras e pistas esportivas, o nome da gloriosa Faculdade de Direito nas competições universitárias.

Com o treino de exímia e premiada corredora, a colega Ada tomava a dianteira nessas provas, e assim foi também depois na sua vida profissional, conquistando láurea após láurea, ocupando rapidamente espaço no cenário jurídico, 
construindo com competência o seu renome, galgando depressa os degraus da carreira universitária, vindo esperar-me e saudar-me na reta de chegada, eu, que vim devagar, detendo-me nas curvas do caminho mas avançando sempre, impelida pelo estímulo de inúmeras vozes que me animavam e instavam a prosseguir.

A natureza e o contexto desta cerimônia impõem a brevidade de minha manifestação, permitindo-me apenas, por alguns momentos, recordar e agradecer a todos aqueles que marcaram as etapas desta ascensão que hoje se comemora.

A começar pelos meus professores de Direito Penal desta Casa que, nos cursos de especialização ou de pós-graduação, além de solidificar a minha inclinação por essa área jurídica, vieram suprir as falhas de conhecimentos que não puderam ser adquiridos nas agradáveis tertúlias em que consistiram por três anos o nosso curso de Direito Penal, consumido na magnífica oratória e nas cultas digressões do saudoso e querido Professor José Soares de Mello, perito em literatura e civilização francesa.

As lacunas foram, porém, preenchidas aos poucos, com a colaboração eficiente dos professores Basileu Garcia, Manoel Pedro Pimentel, João Bernardino Gonzaga, Miguel Reale Jr., Ricardo Antunes Andreucci e, de maneira especial, da Professora Esther de Figueiredo Ferraz, modelo de jurista, advogada e educadora, pioneira na conquista do acesso feminino ao grupo fechado que caracterizava a Congregação desta Faculdade à sua época. Dela recebi a inspiração e o exemplo no trato de inúmeras questões que confirmaram o nosso interesse comum pelos dramas sociais e humanos, que se escondem sob o manto da crueldade e da frieza nas ações criminosas, e a convicção de que a educação é a melhor arma da sociedade no combate à criminalidade.

Menção especial quero fazer a outro Mestre, presente aqui esta noite, e presente no meu reconhecimento sempiterno, o Professor Paulo José da Costa Jr., que me proporcionou a oportunidade da iniciação na docência de Direito Penal, a matéria que me empolgava, apoiando-me sempre e incentivando-me a construir nesta Faculdade o meu futuro, e que me forneceu os ensinamentos básicos, fundamentais, do Direito Penal Ecológico e da Tutela Penal da Intimidade, dois assuntos que dominava e cujo debate introduziu na nossa literatura jurídica, e que se mostraram tão úteis no meu recente concurso, fornecendo-me preciosos 
elementos para a minha tese e para a prova de erudição, contribuindo assim também para a obtenção do título que ora ostento.

Título esse que me permite vir a ocupar a cadeira prematuramente vaga de um jovem e promissor Professor Titular de Direito Penal, Ricardo Antunes Andreucci, que na sua breve carreira transmitiu-nos suas incessantes inquietações nas reflexões que fazia sobre a crise do Direito Penal, vista como o reflexo de uma conturbação mais ampla, oriunda do próprio homem e de seus valores "postos na temática das oscilações e das instabilidades". segundo suas próprias palavras.

Advogado bem-sucedido, depois competente magistrado, professor respeitado e querido por seus alunos, de cultura invulgar, membro das comissões elaboradoras da Reforma Penal, colaborador de organismos jurídicos e de política penitenciária, sempre preocupado com a dimensão humana no Direito Penal, que o impelia a buscar uma nova concepção de Política Criminal, Ricardo Antunes Andreucci, no auge de sua carreira, e talvez por causa dela, entrou numa crise existencial que o levou a mudar os rumos de sua vida, de forma cabal e completa, deixando de lado tudo o que motivara a sua vida até então, o seu trabalho, os seus estudos, os seus amigos e colegas, os livros e a Faculdade, refugiando-se na solidão de suas lembranças, ou numa nova existência.

Tendo se afastado de tudo e de todos, buscando voluntariamente o esquecimento, que hoje vim perturbar, peço-lhe escusas, mas era necessário, pois não se passa impunemente por este doutoral e estes umbrais sem deixar traços, materiais ou espirituais, incorporados nas Arcadas que abrigam as sombras, nas horas vazias, daqueles que não mais aqui estão presentes.

A aluna, assim, sucedeu ao Mestre, e assume a tarefa inacabada, e perene, de preparar as novas gerações para ocuparem, por sua vez, no seu devido tempo e na sua devida hora, o mesmo lugar e as mesmas incumbências, que esse é o destino desta Casa. Oxalá eu possa fazê-lo com o mesmo denodo e determinação!

Para finalizar, quero agradecer aos membros da minha família, a quem também sou devedora e reconhecida pelas parcelas de suas contribuições ao meu esforço pessoal, nas diversas etapas da minha carreira. Aqui se incluem meus pais, irmãs, marido, filhas e genros, cada qual cooperando a seu modo, física ou espiritualmente, para este feliz epílogo. Menção especial, porém, para minha filha Ligia, perita nas coisas da informática, que nas derradeiras horas do prazo fatal, 
por ter domado a máquina, tornou possível o impossível, e animou-me contra o desânimo, acreditando que eu iria conseguir... Na verdade, consegui. Mas foi com a participação de todos vocês!

\section{Muito obrigada.}

